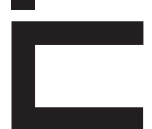

开政正岛

\title{
O MISCIGENADO BRASILEIRO E O ASSIMILADO AUSTRALIANO: DISCURSOS DA ETNO-MUSICOLOGIA NAS DUAS EX-COLÔNIAS EUROPEIAS.
}

Walcler de Lima Mendes Junior ${ }^{1}$

\section{RESUMO}

0 artigo aqui apresentado configura-se como uma análise etnográfica comparada dos processos de colonização e formação de identidade nacional no Brasil e na Austrália. 0 artigo configura-se também como resultado de minha pesquisa na Austrália junto aos departamentos de sociologia e antropologia da Universidade de Newcastle, NSW, com a colaboração dos professores Nick Higginbothan e John Maynnard. Tomo por objeto empírico a produção da música popu-
Lar australiana com características étnicas no intuito de analisar certas relações entre a forma de se pensar a música popular na Austrália, em especial o Rock, o Country e o Folk de músicos aborígenes.

\section{PALAVRAS-CHAVE}

Etnomusicologia. Identidade. Território 


\section{ABSTRACT}

The paper presented here appears as an ethnographic comparative analysis of the processes of colonization and national identity formation in Brazil and Australia. The article also sets up as a result of my research in Australia together with the departments of sociology and anthropology at the University of Newcastle, NSW, with the collaboration of teachers Nick Higginbothan and John Maynnard. Tomo by empirical object the production of the popular Australian music with

\section{RESUMEN}

El artículo que aquí se presenta se presenta como un análisis comparativo etnográfico de los procesos de colonización y la formación de la identidad nacional en Brasil y Australia. El artículo también aparece como resultado de mi investigación en Australia, junto con los departamentos de sociología y antropología de la Universidad de Newcastle, NSW, con la colaboración de profesores Higginbothan Nick y John Maynnard. Tomo por objeto empírico de la producción de la músi- ethnic characteristics in order to examine certain relations between the way of thinking popular music in Australia, especially the Rock, Country and Folk Aboriginal musicians.

\section{KEYWORDS}

Ethnomusicology. Identity.Territory.

ca popular de Australia con características étnicas con El fin de examinar algunas relaciones entre la forma de pensar sobre la música popular en Australia, especialmente los músicos de Rock, Country y Folk aborígenes.

\section{PALABRAS CLAVE}

Etno musicología. Identidad. Territorio 


\section{CULTURA E POLÍTICA: NORTEADORES DE VALOR NA FORMAÇ̃̃O DA IDENTIDADE NACIONAL.}

Propomos neste artigo trabalhar a relação interdiscursiva entre cultura e política, partindo do que foi desenvolvido em nossa tese de doutorado - a relação entre o cancioneiro popular brasileiro e os discursos de identidade e modernidade que se tornaram hegemônicos ao longo do século XX no Brasil. Em síntese, apresentamos aqui uma introdução de uma abordagem em paralelo entre duas formas discursivas: 0 conjunto de vozes referentes ao cancioneiro popular e o conjunto de vozes que constroem uma imagem hegemônica de nação, no Brasil e na Austrália.

Partindo da premissa de que a cultura brasileira moderna reproduziu-se sobre uma base discursiva que reivindicou como valores quase sempre positivos hibridismo e miscigenação, investiga-se que outras positividades sustentaram, no decorrer do século XX, o discurso valorativo das identidades nacionais que, muitas vezes, e de forma contraditória, aliaram à imagem unificadora de povo e nação ações práticas de discriminação e segregação contra parte do mesmo povo constituidor da nação - minorias étnicas, classes populares, descendentes de imigrantes, grupos guetificados.

Grosso modo, os discursos eugênicos e higienistas sustentaram-se pelo longo período histórico de formação e solidificação dos Estados nacionais modernos, como forma de produzir suas singularidades e alteridades culturais que, como nunca antes, precisaram encapsular-se nos limites geopolíticos determinados pelas fronteiras dos Estados, fazendo coincidir raça, nação e território. Mais do que a língua, o rei ou a lei, cada conjunto de Estado e povo precisava singularizar-se e diferenciar-se uns dos outros nas filigranas do cotidiano, dos hábitos, dos valores, dos códigos e das condutas. Era preciso produzir um imaginário de uso específico da nação, da raça e do território, onde transpareceriam singularidades culturais tais como a culinária, os engenhos, a natureza, a história e as artes referentes àquele povo. A afirmação dessas singularidades perante as singularidades alheias expressaria simbolicamente a superioridade de um conjunto de raça-nação-território sobre outro.

Ainda que as políticas eugênicas, segregadoras e higienistas não tenham faltado nas ações práticas do Estado brasileiro, o discurso das "três raças" que constituíram a nação ganhou força no decorrer do século XX. De certa forma, isso já ocorreria no século XIX, por meio de escritores românticos, como José de Alencar e Joaquim Manuel de Macedo, logo depois apoiados por folcloristas como Sílvio Romero e escritores da virada do século como Euclides da Cunha. Porém, foi no século XX que representantes da Semana de 1922 positivam a percepção de nosso hibridismo, fenômeno que ganha força máxima, refletindo na nova sociologia de Gilberto Freyre, em Casa Grande e Senzala e de Sérgio Buarque de Holanda, em Raízes do Brasile na reinvenção dos estudos folclóricos de Câmara Cascudo em Vaqueiros e Cantadores.

Ao longo dos anos sessenta, essa leitura positiva começa a decair quando o mito da democracia racial brasileira é questionado. Essa síntese ligeira e um tanto incompleta sobre alguns dos principais sujeitos e movimentos que fizeram ecoar de forma positiva o discurso da miscigenação cultural no Brasil com base na assimilação da cultura branca hegemônica pelas minorias étnicas, tem função apenas de localização histórico-temporal da questão que propomos abordar.

Exaustivas análises desses discursos, desvelando suas intenções e contradições internas já foram efetuadas. 0 assunto obviamente não se esgota. No sentido de contribuir com outro viés à problemática em questão, propomos introduzir aqui uma análise comparativa entre os discursos identitários e raciais que forjaram e sedimentaram dois Estados nacionais aparentemente tão diferenciados em sua constituição social, política e cultural: Brasil e Austrália. 
A guisa de mapear, grosso modo, dessemelhanças e coincidências, propomos refazer sucintamente um percurso comparativo do discurso identitário no Brasil e na Austrália onde, a priori, juízos de valor positivos sobre cada uma das duas culturas foram produzidos por caminhos opostos. A saber: a cultura brasileira como síntese do hibridismo "natural" do encontro das três raças; a cultura australiana como parte da cultura inglesa, espécie de Inglaterra avançada nos trópicos.

0 discurso de construção nacionalista brasileiro caminha ao longo do século XX, aliviando o peso da cultura europeia e abrindo espaço para uma miscigenação discursiva que forja para si as míticas do exotismo oriental lorubá e Banto africanos e da pureza guarani do ameríndio. No caso australiano, o discurso hegemônico forja para si condição de nação europeia distante, porém não menos branca e homogênea. Duas estratégias que resultaram em consequências sociais e culturais bastante singulares.

Porém, deve-se levar em conta que se por um lado, a segregação produzida na Austrália deu-se de forma explícita, expressando-se no fechamento das fronteiras para orientais, no quase extermínio do povo aborígine e na produção de uma população hegemonicamente branca, por outro lado, não se deve acreditar, no discurso mitológico que afirma o Brasil como democracia racial. Contra essa crença, os indicadores sociais do Instituto Brasileiro de Geografia e Estatística (IBGE) mostram claramente como negros e pardos vêm ocupando lugar nada invejável nos índices de baixa renda, desemprego, violência, população carcerária, evasão escolar, analfabetismo, habitação precária etc.

Em resumo, a miscigenação no Brasil ganha atributo de coisa positiva e na Austrália permanece como valor negativo, mesmo para aqueles que defendiam a cultura aborígene e o multiculturalismo. Considerando essa ambiguidade valorativa entre as duas culturas, chamamos atenção para a possível leitura fenomenológica: se por um lado, a construção do discurso das hierarquias sociais resulta em políticas de segregação em ambas as nações com resultados aparentemente semelhantes (a saber: a espoliação e exclusão do outro, do não branco, apartado dos frutos que os mecanismos de reprodução de riquezas geravam na sociedade), por outro, a produção discursiva que estabelecia o parâmetro valorativo da cultura e da identidade nacional em diálogo com as etnias não dominantes, se apresentava de forma bastante diferenciada entre Brasil e Austrália.

Essa é a contradição que ocuparia, a priori, a razão de ser de nossas investigações na Austrália. Configura-se como que um divórcio entre os dois planos discursivos que constroem imagens da sociedade e da cultura. Como se o discurso de construção racial e identitária, nas duas nações, se estabelecesse por palavras contrárias, mas resultasse em coisas semelhantes.

Por outro lado, deve-se considerar, também, como fator fenomenológico mais atual, que ocorre simultaneamente nas duas sociedades em questão, a seguinte percepção possível: pelo menos nos últimos 20 anos, é inegável a ação de movimentos de afirmação racial, tanto no Brasil quanto na Austrália, que têm procurado corrigir e reavaliar a importância participativa de grupos étnicos na construção do imaginário nacional. Assim, se no Brasil, principalmente o negro, mas também o índio têm assumido lugar e vozes que antes eram de domínio da intelectualidade eminentemente branca, o mesmo fenômeno tem se repetido na Austrália, onde cientistas sociais de origem aborígine re-elaboram análises e reproduzem discursos a partir de sua condição étnica. 0 próprio Prof. John Maynard, colaborador em nossas pesquisas, se autodefine como half-castle, isto é, um aborígene de origem miscigenada.

\section{A REAÇÃO CONTRA HEGEMÔNICA}

Considerando essa ruptura que a contemporaneidade nos apresenta é possível repensar os discursos culturais excludentes ou miscigenadores, por meio do postulado do movimento no tempo e no espaço e não 
como forma cristalizada determinante e determinada por esta ou aquela sociedade, este ou aquele discurso com intuito de produzir esta ou aquela imagem de nação. Claro que os discursos hegemônicos impõem-se como narrativas dominantes que alicerçam a ideia senso-comum de nação. Porém, tais discursos não são completamente imunes às ações conspiratórias, não são monólitos instransponíveis visto que, no nível das microfísicas do poder, contrapoderes germinam para combater na materialidade simbólica e cotidiana dos corpos. É premissa da dominação que os corpos respondam ao poder dos símbolos propostos pelo discurso hegemônico, respondam ao pacto que o discurso hegemônico propõe.

No nível das microfísicas, esse contrapoder no Brasil se exprimiu e se exprime de forma vária. Ontem, foram os sindicatos, os grêmios estudantis, as ligas camponesas e a Igreja progressista. Hoje, associações de moradores, redes comunitárias e grupos de interesse social se organizam para reverter o quadro de desigualdade e injustiça social que reflete a distribuição desigual dos recursos materiais do País entre ricos e pobres, em última instância entre brancos e negros\pardos.

Na Austrália, o mesmo vem ocorrendo por meio da constituição de eventos, grupos e programas de inserção do aborígine e das minorias raciais na sociedade, procurando respeitar as singularidades e aspectos próprios de cada cultura ${ }^{2}$. Porém, o que chamamos de contrapoder (que se dá no nível das microfísicas do poder), não diz respeito somente às organizações políticas, culturais ou às redes sociais. Diz respeito, também, aos discursos que são produzidos de forma mais ou menos coincidente sobre determinado aspecto da sociedade, tais como injustiças, desigualdades, alteridades, etc. Assim, esses discursos que emergem não

2. Iniciativas como a Central Australian Aboriginal Media Service (CAAMA) que possui canal de televisão nacional e publicações distribuídas em todo o território da Austrália, festivais de música como o Survival Day ou o Qantas Austrália Day Concert são alguns exemplos dessa tentativa de aproximação cultural. sólidas vozes de sujeitos das classes populares, mas também de certa elite intelectual simpatizante, vão se constituindo como contrapoderes no nível da microfísica, uma vez que conspiram contra o pacto social da maneira como é proposto pelo discurso hegemônico.

Um exemplo de discurso contra-hegemônico, e não necessariamente emergido de organização sociopolítica, pode ser encontrado no cancioneiro popular brasileiro. A enorme inserção e aprovação da música pela sociedade brasileira, como elemento mediador de certo diálogo entre grupos sociais heterogêneos e espaços urbanos e regionais diferenciados, possibilitou o uso da música popular enquanto gênero discursivo por muitos sujeitos das classes sociais populares. Por meio desta plataforma, que obviamente também foi usada por sujeitos da elite, os sujeitos populares puderam reproduzir discursos que denunciavam a espoliação e a segregação a que eram submetidos.

Não devemos ignorar, também, as contradições discursivas dentro do próprio grupo de sujeitos populares que era em si bastante heterogêneo. Muitas vezes, esses sujeitos seriam cooptados pelo discurso hegemônico para desqualificar as vozes conspiradoras.

Para a cultura aborígine algo um tanto dessemelhante tomou curso na relação com a música europeia. Isto é, a canção aborígine ou foi mantida afastada como que preservada em sua forma mais tradicional, prevenida do sujeito dominador, ou formatou-se à estrutura da música dos gêneros rock, blues e country, majoritariamente executada por brancos, pelo menos na Austrália. Assim, se no samba brasileiro fica quase impossível determinar onde acaba a polca e começa o batuque, isto é, onde se separam os caracteres europeus dos africanos, o mesmo não ocorre na música etno-popular australiana. Nesse caso instrumentos e timbres de origem aborígene foram assimilados pelos modos da música branca - Rock, Folk e Country - que conservaram suas estruturas originais. Por sobre a estrutura da música branca ocidental, a música aborígine pôde produzir letras de protesto, denunciando a sua condição de espoliado e dominado. 
Assim, ainda que de forma diferenciada do que ocorreu no Brasil, no que tange a produção de uma plataforma mediadora expressada pela música popular, parte-se da premissa que o discurso conspiratório também se manifestou dentro da sociedade australiana.

\section{CONTEXTO DE SEGREGACC̃O NO PROCESSO DE COLONIZAÇ̃̃O DA AUSTRÁLIA}

A priori considera-se que a ação segregadora das políticas sociais australianas deu-se sob outras diretrizes, bastante diferente da segregação cordial, que caracterizou as ações de segregação no Brasil. Com o arrefecimento das políticas oficiais de segregação contra as minorias não brancas, a partir de fins dos anos setenta, as condições de organização e luta, assim como de ascensão e mobilidade social do aborígine e demais grupos étnicos minoritários foram objetivamente favorecidas. Porém, a percepção dessa mobilidade, assim como das estratégias de organização política, continua bastante prejudicada e limitada por uma leitura senso-comum por parte da sociedade australiana branca, que reproduz paradigmas de um passado ainda recente de exclusão e preconceito contra o aborígine e o estrangeiro não branco.

Essa leitura excludente baseia-se em certos axiomas da cultura australiana branca, revelando os paradoxos da construção do discurso de identidade, civilização e raça na Austrália, principalmente no que tange o trato com o aborígine empurrado à condição de estrangeiro em seu próprio território.

1) Assim, o processo de construção do discurso nacionalista ao mesmo tempo em que produzia o imaginário de lugar tolerante com o outro, receptivo ao estrangeiro, terra vazia e generosa para o colono, não foi capaz de produzir (ou jamais teve a intenção) um discurso de rompimento com a origem anglo-saxônia, decretando independência cultural e estética em relação ao formato de sociedade europeia. Sem problematizar a questão, e a título de melhor explicar a ideia, basta pensar no quanto a América Latina, ou mesmo os Estados Unidos, afastou-se culturalmente do colonizador europeu e, grosso modo, comparar esse afastamento com o que foi construído simbolicamente pela cultura australiana em relação ao colonizador inglês. 0 primeiro paradoxo se estabelece então no discurso de tolerância com o outro contradito pela construção de uma identidade cultural monolítica que pouco dialoga com qualquer estética não europeia, seja aborígine, seja oriental.

2) A construção discursiva que produz o imaginário de uma sociedade nacional a princípio deve considerar todos os habitantes que nasceram no território nacional referente. Porém, o discurso nacionalista australiano, excessivamente plasmado em sua origem europeia, e, talvez, por isso mesmo, conseguiu produzir um tipo outro como estrangeiro de si e de sua terra de origem. Não como o fizeram os países americanos em relação ao negro escravizado e ao índio assimilado, mas, como se o aborígine pertencesse a uma categoria social extranacional, não abarcada pelo imaginário representativo da cultura australiana. Por isso, os aborígines, apesar de nascidos no solo dos mesmos australianos brancos, não são incorporados na produção de um discurso identitário da nacionalidade australiana. Em síntese, sob o discurso senso-comum da população branca o aborígine é sempre classificado como o outro, um estrangeiro em relação ao australiano branco.

Essas contradições revelam pistas para se pensar o território australiano construído culturalmente como resultado do processo histórico-social que determinou quem é australiano e quem não é a partir da matriz europeia. A construção desse novo território australiano torna crível uma aproximação física entre a Europa e a Oceania de forma muito mais convincente do que aquele sentido de território sedimentado, antes do processo de colonização, pelo olhar do abo- 
rígine ${ }^{3}$. De fato, a reterritorialização expressa na forma discursiva da europeização da Austrália precisava urgentemente, para além de qualquer necessidade do capital, apagar todo traço não europeu para que as bases simbólicas da ideia de civilização pudessem fincar-se de forma positivada sobre aquele território: a priori, já construído pelo mesmo olhar colonizador como terra inóspita e distante 4 .

\section{DISCURSO DO CANCIONEIRO INTERPRETADO PELO DIALOGISMO DE BAKHTIN}

Porém, o que nos interessa de fato é elaborar aqui uma forma de abordar a construção dos ideais de nacionalidade que se estabelece por meio da análise discursiva das expressões culturais em suas intenções e contradições internas. Em nossa pesquisa de doutorado foi realizado um levantamento de grande parte do cancioneiro popular brasileiro, obedecendo a um recorte temporal que principia em fins do século XIX com a emergência da indústria fonográfica e dos discursos pró-miscigenação dos primeiros folcloristas para interromper-se na década de 1960, quando a televisão passa a interferir de forma decisiva no campo da música popular e os movimentos raciais perdem a inocência para desconectarem-se da crença na democracia racial.

Entre esses dois marcos temporais, foram experimentadas, pelos sujeitos do cancioneiro popular, inúmeras estratégias, intenções e contradições discursivas onde o cotidiano era, mais do que traduzido ou representado pela escritura referente ao conjunto das letras das canções, rasurado pelas canções, isto é, reescrito, reconstruído constantemente no campo reflexivo que o cancioneiro popular constituiu-se para uso da sociedade brasileira. 0 jogo de pergunta e resposta entre os sujeitos discursivos dentro desse cam-

3. Ver os mapas da Austrália: oficial e aborígine na página 13.

4. 0 conceito colonial de terra nullius, território vazio, que negava o genocídio provocado pelos colonos e a eugenia produzida pelo governo sobre o povo aborígine, só seria revogado legalmente pelo Estado Australiano em 1992. po reflexivo é analisado a partir de uma metodologia com base na metalinguística de Bakthin ${ }^{5}$.

Segundo essa metodologia os discursos dos sujeitos de dentro do campo do cancioneiro popular ocorrem por meio de relações dialógicas. 0 cancioneiro se constitui de forma dialógica, isto é, considerando e embutindo em seu enunciado aquilo que imagina como resposta do "outro", do destinatário que receberá o enunciado. Esse dialogismo ocorre tanto a partir de trocas entre sujeitos de dentro do campo, como entre sujeitos de dentro e de fora do campo (sujeitos externos ao campo da música que também fazem referência à mesma questão de nação e raça). A vantagem dessa metodologia reside no fato de podermos identificar qual parte do discurso do sujeito discursivo diz de sua intenção e qual parte faz referência a uma estratégia, onde é dito aquilo que o destinatário espera ouvir.

Essa construção discursiva de caráter dialógico do cancioneiro pode se dar por uma postura de adesão ou transgressão ao discurso hegemônico. Dessa forma, o cancioneiro, como crônica social, discursou fixando preconceitos, assim como, denunciando-os, propondo estratégias de ordem e de desordem para os conflitos cotidianos, sociais e políticos. 0 cancioneiro produziu-se como campo reflexivo, como plataforma mediadora, dentro da sociedade brasileira, considerando que indivíduos e grupos podiam reconhecer suas dores e desejos comuns traduzidos nas letras das canções.

5. "Bakthin desenvolve [...] um novo campo de estudos que designa então como metalingüística, cujo foco central é o processo que denomina de relações dialógicas. [...] 0 dialogismo bakthiniano tem por fundamento primeiro a consideração de que toda e qualquer idéia se constitui, objetivada por intermédio de código lingüístico, como um discurso, posto que destinado a outrem" (ARAÚJO et al., 2007, p. 3). "A orientação primordial a outro sujeito discursivo é o que confere, a cada discurso, o caráter dialógico que nenhuma orientação a um objeto pode dar. Por mais que um enunciado se concentre em um objeto, não pode deixar de ser, essencialmente, uma resposta ao já dito acerca do mesmo objeto [...] Assim sendo, todo enunciado deve ser tomado como um elo em uma complexa trama de enunciados componentes da cadeia de comunicação discursiva em uma esfera determinada" (ARAÚJO et al. 2007, p. 4). "O dialogismo [...] diz então das diversas relações de alteridade existentes em qualquer discurso. O destinatário, mais do que uma abstrata meta do enunciado, é também visto como autor deste, na medida em que é em função dele [...] que se define em parte o que será dito efetivamente" (ARAÚJO et al., 2007, p. 5) 
A plataforma mediadora diz respeito à percepção em comum de imagens discursivas que produzem valores simbólicos para boa parte da sociedade brasileira, capaz de achar sujeitos interlocutores em todas as camadas sociais. Essa miríade de construções discursivas que se constitui o cancioneiro popular vai dialogar e interferir com a construção dos discursos nacionais de identidade e modernidade, assim como, com a percepção que o indivíduo fará (1) de si, como indivíduo e pessoa; (2) de povo brasileiro, enquanto raça e identidade; e (3) de nação, como lugar de pertencimento e transformação.

\section{CONCLUSÃO NA FORMA DE QUESTÕES PARA APREENSÃO POSTERIOR}

A despeito da análise da produção musical brasileira, considerada como construção discursiva (discurso como fenômeno que não expressa diferença entre elementos materiais e simbólicos ${ }^{6}$ ), uma questão de fundo investigativo emerge como peça central para uso específico desse exercício analítico comparativo das culturas brasileiras e australianas, respondendo as prerrogativas da metodologia de pesquisa aqui explicitada.

Considerando que não houve na Austrália a produção de uma plataforma mediadora com função semelhante à que o cancioneiro popular se prestou no Brasil, que efeitos de valor simbólico resultam dessa lacuna? Isto é, como e em que medida a ausência dessa plataforma foi determinante para a experiência de não miscigenação que a sociedade australiana reproduziu no decorrer de sua modernidade. Nesse caso, vale aprofundar-se ainda no fato das políticas de se-

6. Não se considera, metodologicamente, o campo pesquisado como que cindido na forma dicotomizada de um real dado e concreto que se contrasta com a representação, como um discurso que se constitui a partir de um real que existiria à priori. Não se trata nem de simples nomeação direta de referentes, nem de representação nominalista (nos termos da episteme clássica), nem de fixar significados nos termos da lingüística tradicional (Foucault, 1966). Daí a ideia de construção reflexiva e dialógica entre os discursos da música e os demais discursos que atuam na construção de um modelo hegemônico de nação e raça. gregação na Austrália terem obtido resultados muito mais eficazes na produção do discurso eugênico e higienista plasmado na ideia de "súditos da rainha" ou "Inglaterra distante" e que resultaram numa raça predominantemente branca e não miscigenada.

Com base em certos princípios da etnomusicologia, pode-se afirmar que o aborígene, no que diz respeito a um escopo de produção musical já em contato com a cultura branca, adotou duas estratégias: ou utilizou a estrutura e forma de ritmos ocidentais como o rock, o country, o blues e o reaggae ou se preservou como música intocada e enraizada em suas origens étnicas no hinterland do grande sertão australiano denominado de "Outback".

Esta divisão expressa sintomaticamente o modelo classificatório do povo aborígine ordenado sob os termos full-blood e half-caste ${ }^{7}$, segundo a análise do discurso dominante construído a partir do olhar do colonizador autor central da etnologia que se debruça sobre a questão aborígine no decorrer do século. Para a antropologia australiana de meados do século, enquanto o full-blood permitiu ao etnólogo repensar a questão racial por meio de uma valorização da cultura aborígine em estado "puro" e de suas práticas da tradição, o half-caste teve de ser excluído e desvalorizado; classificado inclusive como uma ameaça aos paradigmas nacionais de raça homogenia, bastante valiosos à forma discursiva de construir o Estado australiano. Pode-se pensar no half-caste como uma transgressão das barreiras raciais firmadas pelo pensamento hegemônico da sociedade australiana, visto que a miscigenação que o half-caste expressava tornava-se por si uma ameaça aos ideais de homogeneização racial que sustentaram e alimentaram o nacionalismo e o pensar-se australiano.

Assim, se por um lado, foi possível fechar as fronteiras, assegurando a não entrada de imigrantes asiáticos e não brancos, por outro, controlar a mistura

7. Moran, Anthony. White Australia, Settler nationalism and Aboriginal Assimilation 
racial de dentro do próprio país configurou-se como uma tarefa bem mais complexa. De certa forma os discursos de raça e nação não coincidiam, para tanto, seria preciso ou completar o genocídio como proposto e executado no século XIX por colonos ou repensar o próprio paradigma de sociedade homogeneizada pela matriz britânica. Deve-se considerar aqui que a hipótese do genocídio deixaria de se configurar como possibilidade estratégica de controle étnico após a Segunda Guerra, quando essa prática passou a representar ação desumana, despertando repúdio e antipatia no senso-comum mundial.

Interessa sublinhar como a sociologia australiana não conseguiu pensar para si um modelo de sociedade em que certo grau de hibridismo fosse incorporado. A categoria miscigenação guardaria um valor sempre negativo, porque exprimiria em seu apagamento cultural das etnias minoritárias pelo branco. Essa verdade parece alimentar um recalque, como se a matriz do determinismo biológico na sociologia ainda assombrasse o pensamento humanista australiano. Em suma, como se ainda fosse possível crer que por meio de sucessivos cruzamentos raciais chegar-se-ia a uma raça exclusivamente branca, estratégia eugênica proposta por alguns etnólogos em meados do século XX ou, por outro lado que o isolamento fosse garantia de uma "pureza racial" expressa pelo full-blood.

Por recalque ou não, a cultura aborígine foi pensada, a exemplo da classificação full-blood e half-caste, de duas formas rígidas: ou como cultura tradicional ou como cultura que se utilizou de padrões da sociedade branca sem produzir um grau de interferência relevante. Isto é, a cultura aborígine em contato com a cultura dominante produziu pouca interferência, no sentido de pouco transformar e acrescentar à matriz dos modelos estéticos hegemônicos da sociedade branca que, por $\mathrm{si}$, seguiu escutando countryse rocks similares aos produzidos nas demais sociedades modernas ocidentais.

A incorporação tardia de elementos culturais aborígines pela cultura branca só ocorreria a partir de fins dos anos 1980, no bojo do movimento da Word Music, quando instrumentos aborígines como o didjeridu, o boomerang, o clapsticks (bilma) de marcação passaram a dividir com instrumentos modernos da cultura ocidental os arranjos de ritmos com base no rock, no reaggae e no blues, porém rasurados pela métrica do tempo rítmico da música aborígine tradicional. Essa transformação vai se dar também com o apoio de grupos de rock australianos não aborígenes como MidnightOile Men'satWork que apoiam a causa aborígene e denunciam o genocídio praticado contra o povo aborígene e negado pelo governo australiano ao longo do século XX.

Estas bandas de músicos brancos vão projetar músicos aborígenes em festivais de Rock e Country pelo país sob a marca da tolerância e da diversidade cultural. Bandas como o YuthuYindi e Warumpi Band e a cantora Christine Anu de Torres Straitlslanders (etnia aborígene do norte do país) foram os que conquistaram maior destaque propondo um discurso pós-colonialista em que a cultura nacional australiana devia um pedido de desculpas e reconhecimento da presença aborígene como parte constituinte do discurso de nação. Por outro lado o Country e Folk aborígene ganham força de música de protesto denunciando espoliações, exclusão e preconceitos étnico-raciais contra os não brancos. Jimmy Little, cantor aborígene de música countryafirma que " $O$ fato em si de um artista aborígene subir no palco e cantar é um ato político" (Trad. do autor)"8.

\begin{abstract}
YothuYindi, que inclui brancos assim como músicos aborígenes em sua formação, encabeçou uma hibridização significativa da musica tradicional, tecnologias do rock e da dance music, tocando e cantando uma mistura de musica tradicional djatpangarri dos clãs Gumatj e Rirratjingu do nordeste de Arnhem e rock de pub, comreggae e mesmo influencias de calipso. 0 nome YothuYindi significa mãe e filho, com um significado maior de família e tribo.0 líder da banda, MandawuyYunupingu enfatiza suas preocupações com educação considerando um crescimento da compreensão
\end{abstract}

8. The very fact than a aboriginal performer gets on stage and sings is a political act (MITCHELL, 1996, p. 177). 
cultural entre aborígenes e brancos. Como Yunupingu disse a revista New Music Express: nosso único propósito como banda é desenvolver e criar impacto para nossa cultura envolvendo pessoas da civilização ocidental em nosso modo de ver o mundo. Musica tem uma linguagem universal que pode fazer isso ${ }^{9}$ (Tradução do autor).

Esse tipo de estratégia, também, despertou a crítica baseada na ideia de autenticidade e pureza cultural, acusando grupos híbridos de conspurcar a cultura aborígene real. A resposta de Yunupingu foi categórica: "Nós não queremos ser uma peça de museu. Nós objetivamos tornar as pessoas conscientes de que nós temos uma cultura única que pode coexistir com a cultura ocidental" ${ }^{10}$ (Tradução do autor). Por fim, podemos afirmar que diferente do conjunto de processos socioculturais que caracterizaram a produção da música popular no Brasil, a música popular na Austrália parece só apresentar alguma hibridização a partir da concepção do movimento expresso no termo world music como fenômeno que ocorre pela iniciativa de artistas europeus e norte-americanos ao longo dos anos oitenta e noventa.

Assim, ainda que a fala aborígine tenha se utilizado dos ritmos brancos como o rock, o folk, o blues e o country para denunciar sua condição na sociedade australiana (inclusive incorporando instrumentos de sua cultura mais tradicional), a música aborígine, enquanto estrutura rítmica e melódica parece ter produzido pouca interferência na música branca, quando comparada, por exemplo, com a influência

9. YothuYindi, who include White as well as aboriginalmusicians in theirline-up, wereattheforefrontof a significanthybridisationof tradicional music, rock and dance technologies, playingandsinging a blendof tradicional djatpangarrimusicofGumatjandRirratjinguclansof North East Arnhem Land and pub rock, with reggae, andevencalypsoinfluences. The name Yothu Yindimeans mother and child, with broader signification of Family and tribe, and groupleader Mandawuy Yunupingu emphasizes their educacional concerns within creasing cultural understanding between Aboriginal people and Balada (White australians), [...]. As Yunupingu [...] told to the New Music Express: 'our sole purpose as a bandisthatwe are trying todevelop and create impact for our culture, envolve people from Western civilisation in our world view. And musichas a universal language that can convery that' (MITCHELL, 1996, p.179).

10. Wedon'twanttobe a museum piece. Weaim to make people aware that we have a unique culture that canco-exist with Western culture (MITCHELL , 1996, p. 182) que a música de origem ameríndia e negra operou na música brasileira, praticamente, impossibilitando afirmar o que seria tipicamente europeu ou não em gêneros como o Choro, o Samba urbano, a Marcha carnavalesca etc.

Figura 1 - Mapa oficial (esquerda) e mapa de povos aborígines (direita)

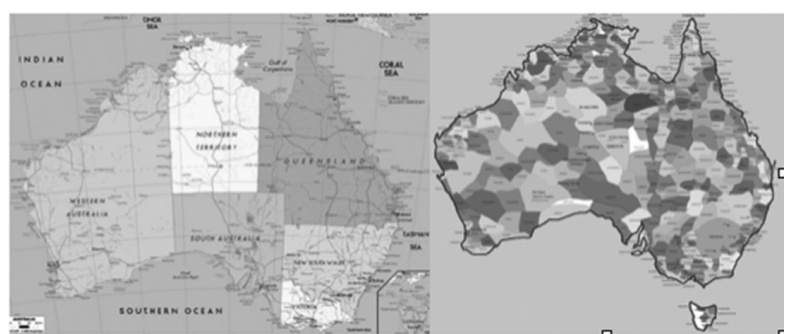

Fonte: Australian Journal of Politics and History, v.51, n.2, 2005

\section{REFERÊNCIAS}

ARAÚJO, Frederico Guilherme Bandeira et al. Para compreender o discurso: uma proposição metodológica de inspiração bakhtiniana, Rio de Janeiro: GPMC/ IPPUR/UFRJ, 2007.

ARAÚJO, Frederico Guilherme Bandeira. Identidade e território enquanto simulacros discursivos. In: (org.) ARAÚJO, Frederico Guilherme Bandeira de; HAESBAERT, Rogério. Identidades e territórios. Questões e olhares Contemporâneos. Rio de Janeiro: Access, 2007.

FOUCAULT, Michel. As palavras e as coisas: uma arqueologia das ciências humanas. São Paulo: Livraria Martins fontes, 1966.

GILBERT, Kevin. Black Australia. An anthology of aboriginal poetry. Australia: Penguin Books, 1988.

HAESBAERT, Rogério. Identidades territoriais: entre a multiterritorialidade e a reclusão territorial (ou: do 
hibridismo cultural à essencialização das identidades). In: (org.)

ARAÚJO, Frederico Guilherme Bandeira de; HAESBAERT, Rogério. Identidades e territórios. Questões e olhares Contemporâneos. Rio de Janeiro: Access, 2007.

KUNST, Jaap. Ethnomusicology. A study of its nature, its problems, methods and representative personalities to which is added a bibliography. Netherlands: Martinus Nijhoff, The Hague, 1974.

MITCHELL, Tony. Popular music and local identity: rock, pop and rap in Europe and Oceania. London: Leicester University Press, 1996.

MORAN, Anthony. White Australia, Settler Nationalism and Aboriginal Assimilation. Australian Journal of Politics and History, v.51, n.2, 2005, p.168-193. (C) 2005 Department of History, School of Political Science and International Studies, The University of Queensland and Blackwell Publishing Asia Pty Ltd.

NETTI, Bruno. The study of ethnomusicology. Twenty-nine issues and concepts. United States: Board of Trustees of University of Illinois, 1983.
SANDRONI, Carlos. Adeus à MPB. In: (org.) CAVALCANTE, Berenice; STARLING, Heloisa M. M.; EISENBERG, José). Decantando a república: inventário histórico e político da canção popular moderna brasileira. Rio de janeiro: Nova Fronteira S. A., 2004, v.1. Outras conversas sobre os jeitos da canção.

SANDRONI, Carlos. Feitiço decente: transformações do samba no Rio de Janeiro (1917 - 1933). Rio de Janeiro: Jorge Zahar/UFRJ, 2001.

SODRÉ, Muniz. 0 terreiro e a cidade: a forma social negro-brasileira. Rio de Janeiro: Imago; Salvador-BA: Fundação cultural do Estado da Bahia, 2002.

SODRÉ, Muniz. Samba: o dono do corpo. Rio de Janeiro: Codecri, 1979.

VIANNA, Hermano. 0 mistério do samba. Rio de janeiro: Jorge Zahar/UFRJ, 1995.

WALKER, Clinton. Buried Country: The story of Aboriginal country musical. Australia: Pluto Press, 2000. 